\title{
Family Business Review
}

http://fbr.sagepub.com

On the Emotional Value of Owning a Firm

Thomas M. Zellweger and Joseph H. Astrachan

Family Business Review 2008; 21; 347

DOI: $10.1177 / 08944865080210040106$

The online version of this article can be found at: http://fbr.sagepub.com/cgi/content/abstract/21/4/347

\author{
Published by: \\ (9)SAGE \\ http://www.sagepublications.com
}

On behalf of:

Family Firm Institute

Additional services and information for Family Business Review can be found at:

Email Alerts: http://fbr.sagepub.com/cgi/alerts

Subscriptions: http://fbr.sagepub.com/subscriptions

Reprints: http://www.sagepub.com/journalsReprints.nav

Permissions: http://www.sagepub.com/journalsPermissions.nav

Citations http://fbr.sagepub.com/cgi/content/refs/21/4/347 


\title{
On the Emotional Value of Owning a Firm
}

\author{
Thomas M. Zellweger, Joseph H. Astrachan
}

\begin{abstract}
This article examines how owners of firms subjectively value their ownership stake in monetary terms. We utilize endowment and possession attachment literature to investigate how emotional benefits and costs related to organizational ownership affect emotional value. We define emotional value as that part of willingness to accept unexplained by the financial value of the ownership stake and the private financial benefits of control accruing to the owner. Our research provides new insight into firm owners' psychology and value considerations where an owner values nonfinancial aspects of the ownership stake.
\end{abstract}

\section{Introduction}

This article examines how owners of firms subjectively value their ownership stake in monetary terms when asked at what price they are willing to sell it. We focus on the relevance of nonfinancial aspects of owning a firm, given that firm owners have long been known to value nonfinancial aspects of their ownership stake (Schumpeter, 1934). In the context of this question, "willingness to accept," the minimum price at which an owner is willing to sell a possession, has been proposed to be a central concept in understanding the value an asset has to its owner. It indicates how owners subjectively value their possessions, including financial and nonfinancial aspects of ownership (Knetsch \& Sinden, 1984; Knez, Smith, \& Williams, 1985). Based on endowment theory, willingness to accept literature shows that assets that seem to be part of an individual's endowment are valued more highly than assets not included in the present endowment (Kahneman, Knetsch, \& Thaler, 1990). That is, when people are given an asset and asked to indicate the price at which they are willing to sell it, they indicate higher values than they do when asked to indicate a price at which they are willing to acquire the same asset.
This gap between willingness to sell and willingness to acquire represents the monetary value placed on the nonfinancial benefit of owning the asset. Endowment literature proposes that when indicating willingness to accept, sellers of endowed assets tend to focus on their sentiment toward surrendering the asset and also price emotional aspects of the ownership stake, beyond the pure financial aspect of the endowed asset (Knetsch \& Sinden, 1984). In contrast to acquisition prices, selling prices have been found to be more heavily influenced by variables such as benefits and costs of possessing the assets (Carmon \& Ariely, 2000).

Willingness to accept (WTA) studies have been performed on a large array of assets of private goods and public goods (for an overview, refer to Horowitz \& McConnell, 2002). To our knowledge, willingness to accept has not been analyzed in the context of organizational ownership. This is surprising, given that owners of firms, particularly privately held and family firms, have long been known to display benefits beyond the financial aspects of the ownership stakes in their firms (Aghion \& Bolton, 1992; Anderson \& Reeb, 2003; Demsetz \& Lehn, 1985; Fama \& Jensen, 1983; Gomez-Mejia, Nunez-Nickel, \& Gutierrez,2001; Zahra, 1993).Schumpeter (1934) 
proposed that owner-managers tend to value aspects like challenge and social status related to their ownership stake. In addition, emotional benefits have been found to distort managerial decisions. For example, Duhaime and Grant (1984) find that divested business units for which owners or managers felt some attachment induced, at least partly, by emotional benefits deteriorated to unprofitability before divestment. Therefore, since emotional aspects seem to prevent more timely decisions, thereby inducing economic loss, they have an economic value in themselves and affect willingness to accept. However, positive nonfinancial aspects of firm ownership may be only one source of endowment. Owners often experience negative nonfinancial aspects of firm ownership (e.g., reputational risks, role conflicts, social constraints) (Dyck \& Zingales, 2004; Sharma \& Manikutty, 2005). It is not clear yet how these negative emotional aspects of firm ownership affect endowment considerations in the context of firm ownership and how they impact willingness to accept.

In this context, the goal of our study is threefold. First, we develop a conceptual framework of willingness to accept in the context of organizational ownership by referring to endowment theory (e.g., Ariely, Huber, \& Wertenbroch, 2005; Strahilevitz \& Loewenstein, 1998; Thaler, 1983) and possession attachment literature (e.g., Belk, 1987; Schultz-Kleine \& Menzel-Baker, 2004; Wallendorf \& Arnould, 1988). Second, we investigate the impact of emotional benefits and costs related to the organizational ownership stake as antecedents of willingness to accept. Third, we introduce a framework with empirically testable propositions for emotional value. We define emotional value as that part of willingness to accept unexplained by the financial aspect of the ownership stake captured in the financial value of the firm and the present value of the private benefits of control, but that is subjectively valued by the owner in terms of endowed emotional benefits and costs related to the ownership stake. Given these considerations, our focus rests on ownership in privately held firms. Investigating the nonfinancial aspects of organizational ownership is particularly relevant in the context of privately held family firms, since it is widely acknowledged that most family firms deliberately strive for a mix of pecuniary and nonpecuniary performance outcomes (Westhead \& Cowling, 1997). Common examples of such nonpecuniary outcomes are independence, tradition, and continuity (Anderson \& Reeb, 2003; Corbetta \& Salvato, 2004; Sharma, Chrisman, \& Chua, 1997; Sorenson, 1999; Ward, 1997). In the family firm context, it is key to better understand in what way these nonfinancial aspects are actually endowed and valued by owners. Whereas the research mentioned above has highlighted the existence and relevance of these nonfinancial performance dimensions, we strive to show how they enter the value considerations of owners.

In the remainder of the article, we first provide the theoretical foundations for our considerations and introduce the concept of emotional value. We then discuss how emotional costs and benefits related to firm ownership are endowed and relate to emotional value. Finally, we conclude and discuss our findings and their implications for researchers and practitioners.

\section{Theoretical Foundations}

As outlined above, we utilize possession attachment (Belk, 1987, 1988; Richins, 1994b; SchultzKleine \& Menzel-Baker, 2004; Watson, 1992) and endowment literature (Ariely et al., 2005; Knetsch \& Sinden, 1984; Shogren, Shin, Haes, \& Kliebenstein, 1994; Thaler, 1980) as theoretical lenses to highlight the impact of emotional benefits and costs on willingness to accept.

\section{Possession Attachment}

Literature on possession attachment investigates the multifaceted property of the relationship between a specific individual and a specific possession (Schultz-Kleine \& Menzel-Baker, 2004). Richins (1994a) defines possession attachment as the extent to which an object that is owned, expected to be owned, or previously owned by an individual is used by that individual to maintain his or her self-concept. Thus, material object 
attachment does not necessarily require legal or physical possession, only psychological appropriation, that is, a sense that the object is "mine" (Belk, 1992). Tuan (1980, p. 472) argues that "the fragile sense of self needs support, and this we get by having and possessing things because, to a large degree, we are what we have."

Attachment develops as a consequence of meanings that are given to a possession (Richins, 1994b). Whereas certain dimensions of meaning that are discussed in the possession attachment literature are normally less relevant in the context of ownership of firms (e.g., sacred and aesthetic meanings), other dimensions of meaning are more applicable. For example, financial meaning relates to a possession's role in providing financial utility. Clearly, ownership in a firm is often sought for financial reasons.

Furthermore, organizational ownership can have value for its role in expressing or reinforcing the sense of self. This motivation is operative when respondents value a possession for its links and overlaps with their own identity or when possessions represent one's competence, mastery, or achievement (Csikszentmihalyi \& RochbergHalton, 1981). Regarding the context of organizational ownership, Schneider (1987) reports a strong overlap between controlling owners, in particular founders, with the goals, processes, and structures of their organizations. Similarly, Dyer and Whetten (2006) report that family firm owners, in particular, often extend their selves into their organizations, given that in family firms the names of family members are identified with the organization, often even represented by identical family and company names, that is, eponyms. Such expressions and extensions of the self in organizational ownership can also be seen with entrepreneurs such as Richard Branson from Virgin, who might strive for a young, dynamic, and risk-liking identity for himself and his firm, whereas Ingvar Kamprad from IKEA strives to stand for a modest, genuine, simple, and thrifty personal and organizational identity.

Additionally, possession attachment literature has long recognized the importance of goods in forming and symbolizing social relationships. For example, possessions that are gifts from a loved one, or objects that were made by or previouslybelonged to a relative, are likely to be valued as symbolic representations or reminders of interpersonal ties. In the context of organizational ownership, attachment induced by representations of interpersonal ties has been reported by Sharma and Manikutty (2005), who propose that owners of family firms are particularly inclined to display attachment to their ownership stake due to emotional bonds between owners, nostalgia, and family tradition. Similarly, Gomez-Mejia, Takacs Haynes, Nunez Nickel, Jacobson, and Moyano-Fuentes (2007) report that attachment develops due to socioemotional wealth, defined as nonfinancial aspects of ownership that meet the owner's affective needs, such as the perpetuation of control inside the family.

In sum, the possession attachment literature suggests that organizational ownership is likely to develop attachment since this type of ownership is expensive, reflective of the owner's self, often "personalized" by the efforts owners put into their firms, and reflective of the individual's roles in the social context.

\section{Endowment and Willingness to Accept}

As a second theoretical foundation, we refer to endowment theory. Thaler (1980) finds that assets that seem to be part of individuals' endowment are valued more highly_it takes a more advantageous offer for these assets to be given up-than assets that are not included in the individuals' present endowment. The endowment effect occurs when an individual becomes attached to the good because he or she is often rewarded for doing so (Knetsch \& Sinden, 1984; Shogren et al., 1994).

One of the central concepts used to measure endowment is willingness to accept (WTA). WTA is defined as the minimum "selling price," the price at which an individual would be willing to sell an endowed good (Knetsch \& Sinden, 1984; Knez et al., 1985). Carmon and Ariely (2000) report that when sellers of endowed assets indicate WTA, they tend to focus on their sentiment toward surrendering the asset. Selling prices are hence more heavily influenced by variables such as 
benefits and costs of possessing the asset. In this context, endowment theory suggests that owners endow not only benefits but also costs related to the possession (Knez et al., 1985; Strahilevitz \& Loewenstein, 1998; Thaler, 1983).

Applying these considerations on endowment and willingness to accept to organizational ownership, we expect that the emotional benefits and costs that owners derive from firm ownership will affect endowment considerations. Regarding benefits, we expect that an affective relation between an owner and his or her firm will positively affect endowment and willingness to accept, since individuals display a greater reluctance to give up affect-rich than affect-poor items (Schultz-Kleine \& Menzel-Baker, 2004). Indeed, with regard to family firms, it has been reported that incumbents have problems in letting go, since they have endowed the emotional benefits, such as stature in the community (Le Breton-Miller, Miller, \& Steier, 2004). The strength of this attachment may be indicated by behavioral tendencies such as willingness to sell possessions only above or for market value or to discard objects after their functional use is gone (Belk, 1991). Whereas the link between emotional benefits and willingness to accept is rather straightforward, how emotional costs (e.g., stress, strain, work-family conflicts) are endowed and valued by the owner needs to be clarified.

\section{Emotional Value}

In the realm of understanding what values owners derive from their stake beyond its equity value, literature on controlling ownership premium and on private benefits of control has provided significant insight (e.g., Grossman \& Hart, 1980; La Porta, Lopez-De-Silanes, Shleifer, \& Vishny, 2002). Dyck and Zingales (2004), for example, report that the value of private benefits of control can make up to $14 \%$ of an equity stake. However, even in the private benefits of control literature, the relevance of noneconomic "psychic" elements accruing to the owner has been acknowledged (e.g., Aghion \& Bolton, 1992; Ehrhardt \& Nowak, 2003). Harris and Raviv (1988) even propose that financial benefits of control are unable to fully explain the difference in equity value considerations between buyer and seller in case of takeover bids.

Consequently we introduce the concept of emotional value capturing that part of WTA unexplained by the financial value of the ownership stake, which is captured in the present value of the firm's cash flows, and by the private benefits of control, captured in the present value of the amount of financial benefits that controlling shareholders extract from companies they run. More formally stated:

$$
\begin{aligned}
\text { Emotional Value }= & \text { WTA }- \text { Financial Value } \\
& - \text { Private Benefits of Control. }
\end{aligned}
$$

Hence, emotional value represents the emotional part of WTA once we have excluded any rational financial behavior by the owner. ${ }^{1}$ Emotional value can be seen as the residual between financial flows to the owner and the minimum price at which he or she is willing to sell. We expect that the owner's inclination to sell his or her ownership stake will depend on the level of emotional value, with increasing levels of emotional value negatively affecting the likelihood of a sale. Having said this, we hasten to add that there are many factors other than emotional value experienced by the seller. For instance, organizational issues (e.g., product life cycle and portfolio), environmental aspects (e.g., competitive pressure), and value considerations on the buyer's side all have an impact on the probability of a sale. However, ceteris paribus, we expect that the likelihood of a transfer of the ownership stake rises with diminishing emotional value. Formally stated:

Proposition 1. Ceteris paribus, the likelihood of a sale of the ownership stake is negatively related to emotional value.

In our attempt to explore antecedents of emotional value, we will explore how emotional benefits and, in particular, emotional costs affect the

\footnotetext{
${ }^{1}$ This is similar to Zellweger (2006), who proposes the term "total value" instead of willingness to accept. However, Zellweger's (2006) study neither presents an integral framework for owners' considerations of emotional benefits and costs nor utilizes possession attachment and endowment theory.
} 
On the Emotional Value of Owning a Firm

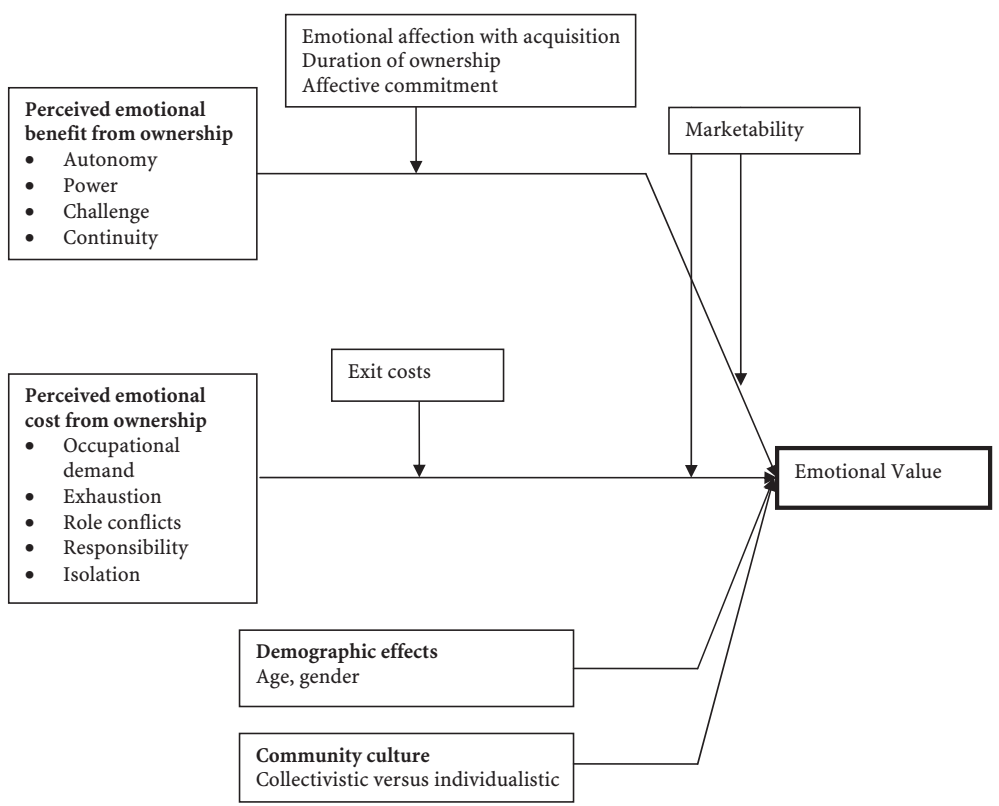

Figure 1 Research Framework.

value considerations of firm owners. To this end, we propose the research framework depicted in Figure 1, which we will discuss in detail below.

\section{Endowed Emotional Benefits}

Entrepreneurship research provides an extensive list of emotional benefits related to an ownership stake in a firm. It has been reported that firm owners derive value from power and prestige (Baumol, 1990), satisfaction with the level of challenge (Naughton, 1987), and autonomy and independent decision making (Douglas \& Shepherd, 2000; Gimeno, Folta, Cooper, \& Woo, 1997). Similarly, family business research reports that owners derive value from passing on the legacy of the enterprising family tradition, emotional bonds between family members, and nostalgia (Sharma \& Manikutty, 2005; Villalonga \& Amit, 2006).

In the context of the question of how owners appropriate these benefits, endowment theory shows that potential sellers focus on the foregone, on their sentiment toward surrendering the possession, and on the act of giving up. Hence, poten- tial sellers are influenced by variables such as the benefits of possessing the item (Carmon \& Ariely, 2000), especially in the case of affect-rich goods. Evaluation of what owners give up as sellers is influenced by such factors as the perceived importance of ownership or the attitude toward surrendering the possession. We therefore expect that controlling owners endow the above-outlined emotional benefits related to firm ownership in an attempt to protect themselves against a feeling of regret that might accompany a deliberately made change in asset position (Knetsch \& Sinden, 1984). Thus, a cost of future regret is imposed on making a change in asset position, which raises willingness to accept and emotional value. In the context of controlling owners, this means, for example, that the more positive autonomy is perceived, the higher the aversion to regret the potential loss of autonomy and, consequently, the higher the required compensation for the foregone loss captured in emotional value.

We expect, however, that the degree to which emotional benefits of business ownership transfer into emotional value is supported by the emotional 
affection with the acquisition of the possession. Emotional affection with the acquisition often depends on acquisition type, on whether the firm was received as a gift (e.g., as a heritage), or on whether it was bought on an anonymous market for corporate control. Strahilevitz and Loewenstein (1998) find that most cherished possessions, possessions for which people tended to display the highest attachment, were gifts that remind them of a friend or family member. Schultz-Kleine, Kleine, and Allen (1995) find that successful gifts, gifts that represent the receiver's "me" or positively symbolize the relation between the giver and the receiver, have the highest capacity to create attachment since they are loaded with positive emotional affection. Indeed, Shepherd and Zacharakis (2000) show that how the business was actually obtained affects an owner's willingness to sell the business.

In contrast to successful gifts, gifts can also have the opposite effect, if they work as "golden handcuffs" or if the owner receives them against his or her will. Unsuccessful gifts, even though carrying reminding the receiver of a friend or family member, can provide incentives to sell it at lower prices. In line with these considerations, we therefore suggest that depending on the level of emotional affection with the acquisition, the relation between emotional benefits and emotional value will be supported. The presence of high levels of emotional affection with the acquisition, in particular when the acquisition of the firm is seen as a successful gift from family members, increases the compensation considerations as a protection against a feeling of regret in case of a sale. More formally:

Proposition 2a. The positive relation between endowed emotional benefits and emotional value is moderated by positive emotional affection related to the acquisition, high levels of positive emotional affection related to the acquisition bolstering the emotional benefits-emotional value relation.

Possession attachment studies report that willingness to accept is affected by ownership history (e.g., Ariely et al., 2005; Strahilevitz \& Loewenstein, 1998). These studies show that endowment and valuation increase with the duration of current ownership. For objects not in one's possession, previous ownership experience increases valuation as well. That increase appears to be related to the duration of ownership before loss. In a similar vein, Ariely et al. (2005) show that higher valuations of items once owned persist for some period. That is, owners continue to value the possession even after they have lost it and that positive valuation diminishes with time only. Commenting on the processes through which feelings of ownership likely emerge, Weil states that "all men have an invincible inclination to appropriate in their own minds, anything which over a long, uninterrupted period they have used for their work, pleasure, or the necessities of life" (1952, p. 33). With regard to firm ownership, Kets de Vries (1993), for example, suggests that family firm owners may stay in power for nonfinancial benefits even though performance results do not justify their continued tenure. In this vein, Schroeder (2001), just like Gomez-Mejia, LarrazaKintana, and Makri (2003), finds that the emotional ties with the firm that the owner experiences tend to increase with ongoing tenure. These emotional ties are hence valued more highly by the owner with increasing duration of ownership and translate into significant barriers to leaving the daily operations, hence increasing emotional value. Therefore, we expect that increasing duration of ownership supports the relation between emotional benefits and emotional value. In contrast to long ownership tenures, we expect that in case of short ownership periods, emotional value is less likely to develop. More formally stated:

Proposition $2 b$. The relation between endowed emotional benefits and emotional value is moderated by the duration of ownership, longer ownership duration supporting the emotional benefits-emotional value relation.

The degree to which emotional benefits of business ownership transfer into emotional value is expected to be supported by affective commitment toward the ownership stake. Affective commitment is defined as an attachment characterized by an 
identification with and involvement in an organization and has been found to be induced by, among other factors, work experience, in terms of comfort, competence, and autonomous decision making (Herscovitch \& Meyer, 2002). With regard to possession attachment, Belk (1988) notes that individuals endow possessions by continuous caring and active involvement, since the continuous affective interaction connects the self and the possession.

Since individuals are more hesitant to give up affect-filled than affect-free goods and since affective commitment develops attachment as a result of affect-loaded interaction (Meyer, Allen, \& Smith, 1993), we expect that the affective commitment that a firm owner experiences for his or her possession will strengthen the link between endowed emotional benefits and emotional value. For example, if there are multiple owners of a firm, we expect that not all owners will be aligned in their endowment considerations; rather, we would expect differences in compensation considerations in case of a sale, dependent on the affective commitment for that possession. We anticipate that an owner who is not involved in the operations or the governance of the firm will have a lower affective commitment in the firm compared to an owner who is actively involved in the management and the governance board of the firm. In the latter case, the ownership stake will have more of a decommodified, singular, and personalized meaning to the owner and therefore a high emotional value. Hence, we expect that affective commitment will bolster the link between experienced emotional benefits and emotional value. Formally stated:

Proposition 2c. The relation between endowed emotional benefits and emotional value is moderated by affective commitment, with high levels of affective commitment supporting the emotional benefits-emotional value relation.

\section{Endowed Emotional Costs}

A large array of entrepreneurship research shows that owner-managers experience various types of emotional costs related to their ownership stake, for example, personal sacrifices, burden of responsibility, risk exposure, dominance of professional life, role ambiguity and related work-family conflicts, deadline pressure, stress, long working hours, isolation, a lack of opportunity to interact, and responsibility for the organization and employees (Boyd \& Gumpert, 1983; Douglas \& Shepherd, 2000; Mack \& McGee, 2001; Tetrick, Slack, Sinclair, \& Da Silva, 2000).

Whereas employees, when facing excessive pressure, tend to display withdrawal behavior and hence leave the organization (Mayes \& Ganster, 1988), large blockholders, particularly in privately held organizations, often consider exit from the organization as very costly, given the effort they have put into the business. Hence, controlling owners face sunk costs deriving from the various emotional costs outlined above (Shepherd \& Zacharakis, 2000). These costs bias the decision toward not exiting in an attempt to avoid wasting already expended resources (Arkes \& Ayton, 1999).

In line with the above sunk cost considerations, we expect that owners facing emotional costs related to their firm ownership stake will, to avoid waste, strive for compensation for the endowed sunk costs, and hence indicate an increased emotional value. Similarly, given the time and effort invested in the firm, owners might consider missed alternative opportunities when valuing the sunk costs. For example, owners might consider that as employees they would have been able to trade monetary compensation in exchange for job-related stress (Mack \& McGee, 2001). Indeed, in the context of future family firm owners, Shepherd and Zacharakis (2000) find that the higher the investment of effort and time in the firm, the greater the perception of value for the ownership stake.

However, these compensation considerations are expected to be limited, depending on the size of the endowed emotional costs. This consideration is related to the question about the level at which sunk cost considerations induced by emotional costs decrease or cease to exist and the stage at which owners start displaying disattachment (Ball \& Tasaki, 1992) and want to get 
rid of the asset, even if this means accepting a lower selling price. This could, for example, be provoked by a physical or psychological breaking point, the bankruptcy of the firm, or when the firm was inherited and the role as owner was not wanted (i.e., unsuccessful gift). Shogren et al. (1994) present preliminary evidence for the existence of such a threshold where the importance or size of the endowment drives behavior.

Therefore, we expect that owner-managers who feel emotional costs related to the ownership stake will price these endowed costs in an attempt to avoid wasting their efforts, but only up to a certain level. Beyond this point, when emotional costs become excessive, we expect that the owners will display a lower emotional value. More formally stated:

Proposition 3. Perceived emotional costs of firm ownership are inversely $U$ shaped to emotional value.

In addition, we expect that exit costs related to the withdrawal from the firm can bolster the link between perceived emotional costs of firm ownership and compensation considerations reflected in emotional value. Mayes and Ganster (1988) propose that individuals under emotional stress can exhibit either aggressive or exit behaviors. However, owner-managers of unlisted firms often consider exiting the organization as hardly conceivable since it appears to be very costly.

Exit costs of leaving an organization can be diverging in nature. Meyer et al. (1993) propose that organizational members might experience exit costs due to a lack of alternative employment opportunities, potentially caused by firm-specific investments in human capital and sunk costs related to the personal commitment put into the firm. Additionally, exit costs can be firm-specific investments in financial capital; if there is an inability to trade the equity stake on a liquid market, owners then face illiquidity discounts for their shares (Chatterjee, Lubatkin, \& Schulze, 1999).

Shepherd and Zacharakis (2000) provideimplicit evidence of these considerations by finding that if owners spent considerable amounts of personal wealth when acquiring their firms, thereby raising exit costs, they tend to indicate higher values for their firms. Family owners face a further exit hurdle in the identity overlap between the owner, the family, and the firm (Dyer \& Whetten, 2006). The specific problem resulting from this identity overlap is that in response to emotional costs (e.g., family quarrels or an undesired family reputation), family owners cannot switch families, or leave the organization easily. Additionally, in the event of several family members involved in the firm's ownership, exit costs might be further increased due to altruism among family members who lose their jobs and their income related to the family ownership (Schulze, Lubatkin, Dino, \& Buchholtz, 2001).

In sum, we expect that in case of high exit costs, sunk cost considerations are reinforced and therefore lead to heightened emotional value. On the contrary, in case of low exit costs, we expect that owners will display lower levels of sunk costs and hence of emotional value, since, for example, human and financial resources can more easily be deployed in another setting. Formally stated:

Proposition $3 a$. The relation between emotional costs and emotional value is moderated by exit costs, with high levels of exit costs supporting the relation between emotional costs and emotional value.

\section{Demographic Variables and Emotional Value}

Possession attachment has been found to vary through the life cycle of individuals and in ways explained by theories about personality development. Children and adolescents tend to use possessions as an integral part of autonomy seeking and affiliation seeking in transitioning toward independence and self-hood (Gulerce, 1991; Winnicott, 1953). In contrast, older persons use material possessions to negotiate life reviews and to extend themselves temporally into the future by giving special possessions (e.g., ownership of the firm) to younger family members (Kamptner, 
$1989,1991)$. In old age, possessions can take over kin-keeping roles, representing social history in a possession (Price, Arnould, \& Folkman-Curasi, 2000).

In the relation between the life cycle of the owner and attachment to possessions, we expect that attachment to firm ownership and hence emotional value will be contingent on whether the owner has the opportunity to hand the firm over to a next family generation, that is, whether the ownership stake develops such a kin-keeping role.

In the absence of a transgenerational perspective, we expect that as they age, owners will become increasingly detached from the ownership stake in the firm, in line with above arguments on possession attachment. Toward the end of his or her professional life cycle, the owner's role adjustment is defined in terms of a diminishing level of involvement and authority in the organization, in response to personal issues (health, age, and other interests), organizational factors (growth, need for change, technological innovations), and environmental pressures (turbulence, uncertainty) (Handler, 1990). This means that due to the absence of endowment considerations for foregone benefits related to the family internal ownership succession, older entrepreneurs are more willing to let go and display lower levels of emotional value for their ownership stake.

In contrast, in cases where the owner experiences the opportunity to pass on ownership within the family, the ownership in the firm will develop a kin-keeping role, representing family history, extending the owner's and the preceding generations' selves into the future. Hence, the opportunity to perpetuate the family ownership legacy increases in value over generations. In the context of family firms, it has been reported that elements such as the family's entrepreneurial and business tradition are indeed valued by the organizing family (Chrisman, Chua, \& Steier, 2005). Consequently, contingent on the opportunity to pass on the baton within the family, firm ownership will develop such a kin-keeping role. Above considerations lead us to the following proposition.
Proposition 4a. In absence of the opportunity to pass on ownership within the family, the age of the owner is negatively related to emotional value. In the presence of an opportunity to pass on ownership within the family, the age of the owner is positively related to emotional value.

There is a vast amount of literature reporting gender differences in possession attachment (e.g., Belk, 1992; Dittmar, 1989; Kamptner, 1989). For example Kamptner (1989, p. 189) notes that women and men pay attention to different things in the environment and may value the same things but for different reasons. Wapner, Demick, and Redondo (1990) note that women are less likely to attribute utilitarian meaning and more likely to attribute comfort functions to possessions than are men. Similarly Schultz-Kleine and MenzelBaker (2004) report that gender studies universally find significant differences in terms of possession attachment. For men, possessions often serve both instrumental (to trade for money or enhance the value of their possession) and expressive functions (signifying relationships). In contrast, women display attachment to possessions for their social connections, for ties to previous generations, and for representational reasons (Wallendorf \& Arnould, 1988). Similarly, Kamptner (1989) notes that males value possessions for utilitarian and self-related reasons, whereas females value possessions primarily for social reasons. These findings are in line with women entrepreneurship studies, which find that the gender perspective alters the value system of individuals (Bird \& Brush, 2002).

Organizational ownership has been found to fulfill both utilitarian and self-related needs, for example, in terms of wealth creation for the individual owner, but also social needs, for example, in terms of creating status and prestige in the community related to the ownership stake (Baumol, 1990; Douglas \& Shepherd, 2000). We therefore expect that to the degree that the specific ownership stake in the firm satisfies utilitarian or selfrelated needs versus social needs, attachment to the ownership stake will differ depending on the gender of the owner. We hypothesize that men will 
display a stronger attachment to organizational ownership stakes that primarily serve to increase the financial value of the ownership stake, whereas women will tend to display a stronger attachment to ownership stakes that serve to satisfy social utility.

Proposition 4b. Gender of the owner affects emotional value.

\section{Cultural Factors and Emotional Value}

Wallendorf and Arnould (1988), just like Watson, Lysosnki, Gillan, and Raymore (2002), find that attachment to favorite possessions varies across cultures. For example, Wallendorf and Arnould (1988) find that individuals from the United States are more attached to favorite objects than are Nigerians. In a cross-cultural study on important possessions Watson et al. (2002) find that New Zealanders are more likely than North Americans to value possessions for interpersonal and financial reasons, but that Americans are more likely to value possessions for utilitarian, appearance, and ownership and control reasons.

Csikszentmihalyi and Rochberg-Halton (1981, p. 239) propose that people experience possession attachment "not because of the material comfort they provide, but for the information they convey about the owner and his or her ties to others." As Wallendorf and Arnould (1988) find, these individual nuances of meaning are overshadowed by cultural differences in the meaning not only of the objects but of possession attachment itself. In their study on strategic divestments in family firms, Sharma and Manikutty (2005) propose that, among other factors, community culture has an impact on attachment and on strategic inertia of family firms. Based on the dimensions of individualismcollectivism identified by Hofstede (2001), Sharma and Manikutty (2005) propose that strategic inertia and attachment might differ depending on whether the organization is embedded in a collectivistic or in an individualistic society.

In collectivistic societies, new businesses may have been created not so much for their economic viability but to provide an independent operation to be managed by a family member (Tagiuri \& Davis, 1992). In this case, business units are created to meet the noneconomic motives of the family collective and thus their retention may be preferable to sale in order to promote family harmony.

In contrast, in individualistic societies, businesses may be merely economic units that are guided by economic principles, such as maximization of returns as described by agency theory (Gomez-Mejia et al., 2001; Schulze et al., 2001). People in individualistic societies are therefore less driven by social constraints and nonfinancial aspects of the ownership stake that would build attachment (Sharma \& Manikutty, 2005). In comparison with owners whose firms are embedded in collectivistic cultures, owners operating in individualistic ones are less likely to feel emotional attachment to their ownership stake.

Based on the above considerations, we expect that a community culture will affect possession attachment and hence emotional value for firm ownership. In particular, we expect that, all other things being equal, owners operating in collectivistic cultures will display a higher emotional value and hence willingness to accept for their ownership stake than owners in individualistic cultures.

Proposition 5. Owners in collectivistic community cultures display higher levels of emotional value than owners in individualistic cultures.

\section{Marketability and Emotional Value}

Controlling ownership stakes, especially in privately held firms, are normally not tradable on liquid markets. Hence, a controlling ownership in a privately held firm cannot be considered as an "ordinary market good" (Horowitz \& McConnell, 2002) for which lower willingness to accept values are found. Therefore, marketability of the ownership stake is expected to reduce possession attachment and emotional value. In line with this consideration Coursey, Hovis, and Schulze (1987, p. 689) find that "individuals may well learn to 
become more rational under the pressure of a competitive market."

In a similar vein, Carmon and Ariely (2000, p.369) find that "substitutability of a good tends to negatively affect Willingness to Accept." Possessions of high affective value due to caring and personal efforts by the owner, as, for example, a newly created firm or a firm that has been owned by the same family for generations, have a decommodified, singular, and personalized meaning to the owners and therefore a high emotional value. Once the ownership stake is made substitutable, as an internal or external capital market, the ownership stake loses its singular and personal value and becomes commodified. Haneman (1991) proposes that the value divergence between willingness to accept and willingness to pay, the latter reflecting market considerations on the value of the good, depends largely on the degree of substitution between goods. Shogren et al. (1994) propose that for market goods with close substitutes that are readily available in commercial outlets, willingness to accept converges toward willingness to pay levels and reference prices, making price comparisons increasingly relevant to the value assessment and suppressing endowment considerations. In contrast, for a nonmarket good with no close substitutes, these value measures diverge.

Considering that one of the innate characteristics of closely held ownership stakes is their nonmarketability, we expect that emotional value will be higher in contrast to a publicly held ownership stake for which market prices are available at all times. However, once marketability is installed (e.g., through flotation on a stock market, or the constitution of a firm internal market for shares), we expect that endowment considerations related to emotional benefits and costs disappear since owners become more rational under the pressure and transparency provided by the market. Therefore, we expect that marketability will weaken the link between emotional costs/benefits and emotional value.

Proposition 6. Marketability of ownership stakes moderates the relations between endowed benefits and costs and emotional value, high levels of marketability weakening the relations between emotional benefits and costs and emotional value.

\section{Discussion and Conclusion}

Our study embarked on developing a conceptual framework of willingness to accept in the context of organizational ownership by referring to endowment theory (e.g., Ariely et al., 2005; Thaler, 1983) and possession attachment literature (e.g., Belk, 1987; Schultz-Kleine \& Menzel-Baker, 2004). We investigated the impact of emotional benefits and costs related to the organizational ownership stake as antecedents of willingness to accept. We introduced a framework with empirically testable propositions for emotional value as that part of willingness to accept unexplained by the financial aspect of the ownership stake. Consequently, emotional value is seen as the residual between willingness to accept on the one hand and the financial value plus the value of private benefits of control on the other hand. In the context of transactions of transfer of corporate control, ceteris paribus, we expect that the likelihood of a transfer diminishes with increasing emotional value.

Given that if the business owner refuses to sell at the market price, no transaction takes place, we need to address the "so what" question of our investigation. In fact, we consider several reasons why studying emotional value and willingness to accept of private firm ownership is insightful even if this value cannot (fully) be capitalized on a market for corporate control.

First, investigating emotional value and willingness to accept as a potential selling price is relevant to determine prices and price ranges for goods since these measures ultimately reflect the perceived net benefit of owning the good. Our findings provide improved insight into the cost-benefit considerations of owning a firm. We improve the understanding about how emotional benefits and costs enter the value considerations of a potential seller, given that these nonfinancial aspects are highly relevant for owners of privately held firms. 
Second, our considerations might help potential buyers and sources of financing in understanding when deals are likely to be closed, considering that the wider the gap between willingness to accept and some market value plus the value of private benefits of control, hence the larger emotional value, ceteris paribus, the less likely it is that the sale will actually take place. However, we should note that many factors other than emotional value to the seller have an impact on whether a firm is sold. These factors, for instance, include organizational issues such as product portfolio, life-cycle considerations, and environmental issues as competitive pressure.

Third, our insights might help those wishing to buy a firm gain a better understanding of the bargaining considerations of the potential seller. To the extent that our findings are applicable to the context of the actual sale of a firm, endowed benefits and costs could be substituted by other emotional, nonfinancial benefits. For example, if a potential seller experiences high emotional value due to the social status associated with ownership, compensation of this endowed benefit could be provided in the form of a new status-providing role, inside or outside the firm, thereby potentially lowering the seller's willingness to accept.

Fourth, for practitioners, that is, owners of privately held firms, it is important to understand the mechanisms that lead to a heightened emotional value. In particular, owners who display high levels of emotional value, for example, due to sunk cost considerations, will have problems in finding buyers and successors for their firms. The issue of diverging value considerations between sellers and buyers is particularly relevant for practitioners and policymakers since it represents an important reason why successions fail (Le Breton-Miller et al., 2004). Furthermore, in the context of family firm owners often having the goal of perpetuating the family ownership legacy, it is important to understand what affects willingness to accept and emotional value. Diverging emotional values among family owners can lead to differing incentives to sell the individual ownership share and thus threaten continued family ownership.
Finally, for practitioners, our findings indicate that family firms may be particularly difficult to sell or buy when the firm provides socioemotional wealth to family owners. The inability to consummate exchanges because of a wide divergence in the buyer's willingness to pay and the seller's willingness to accept has implications for family firm owners who face failure. Efforts must be made to decouple emotional attachments from economic realities if anything is to be salvaged for later generations (e.g., Shepherd, forthcoming; Shepherd, Wiklund, \& Haynie, forthcoming).

\section{Limitations and Guidance for Future Research}

Our considerations of endowment of emotional aspects of firm ownership are not equally relevant and applicable to all types and levels of organizational ownership; they seem to be particularly relevant in the context of privately held firms or, more generally, in the context of owners who value not only the financial aspects but also the emotional aspects related to their ownership stake (e.g., privately held firms, publicly and privately held family firms) (Baumol, 1990; Becker, 1974; Villalonga \& Amit, 2006). However, researchers have found endowment and sunk cost considerations influencing investor behavior even in the case of minority stockholders in publicly quoted firms (Hirshleifer, 2001).

At this stage, we need empirical tests for the outlined research framework. In such attempts, the measurement of emotional value poses a particular challenge. Its measurement, however, is feasible, given that privately held companies are valued regularly for transaction purposes, which process takes into consideration private benefits of control. Hence, we consider emotional value not to be an endogenous variable. To facilitate the empirical investigation of our framework, we propose an alternative way to investigate variance in willingness to accept due to emotional aspects. Instead of calculating the absolute value of emotional value, future researchers can use all variables that explain the financial value of the firm (e.g., operating cash flow, leverage level, profitabil- 
ity, industry growth, industry beta) and variables pertaining to financial private benefits of control (e.g., salary of the owner, private expenses running through company accounts) as control variables. Then, the variables for emotional benefits and costs, just like the demographic variables, can be entered as independent variables. Finally, in the appendix to our study we provide a table with proposed measurements of each one of the variables we use in our framework.

In addition to the proposed relationships, scholars could also study the differing roles of owners, their involvement in the firm, and their ownership fraction. This might provide further insight into the levels of emotional benefits and costs experienced by the owners depending on their involvement. In this context, Gomez-Mejia, Takacs Haynes et al. (2007) find that with the advancing life stages of a family firm (founding owner, sibling partnership, cousin consortium), personal attachment to the firm, self-identification with the firm, the utility generated by the ability to exercise authority, and what they call socioemotional wealth are stronger in early development stages of the firm and weaken as the firm moves into later stages. Hence, the development stage of a family firm might indeed be a further factor affecting emotional value. Whereas our text focuses on the characteristics of the owner, further research might delve into the characteristics of the owned asset inducing emotional value and the emotional value experienced by a potential buyer. In this realm, scholars could test our framework by examining bargaining behavior and value considerations of owners when transactions of corporate control take place. It might be most useful to investigate the processes through which endow- ment considerations induced by emotional benefits and costs are adapted (i.e., lowered) when a firm is sold to a presumably less emotionally involved investor. One could determine how emotional aspects impact willingness to pay, hence the "buying price" at which an individual is willing to acquire. Furthermore, it would be rewarding to examine the question of how sellers are willing to lower their emotional value depending on the type of potential acquirer (e.g., financial investor vs. close friend).

The specific family business context might make certain emotional aspects of ownership more prevalent. On the side of emotional benefits, continuity and tradition might be key benefits. On the side of emotional costs, family internal conflicts impacted by the business might be particularly relevant. Investigating the impact of these specific benefits and costs is particularly relevant in the family business context.

Finally, a further avenue for research relates to the findings by Gimeno et al. (1997), who show that a firm's survival not only depends on the organization's economic performance but also on its specific threshold level of performance. Does endowment of emotional benefits and costs impact, that is, lower, this firm-specific threshold level of performance?

In sum, attachment, endowment, and willingness to accept are crucial constructs in understanding the role and meaning of firms to their owners. This is a new area of organizational ownership research, with far more hypotheses than data points, but with a high impact on the broad understanding of organizational ownership and managerial behavior. 


\section{Appendix: Suggestions for Operationalization of Variables}

\begin{tabular}{|c|c|}
\hline Variable & Measure \\
\hline WTA & $\begin{array}{l}\text { Investigate: "What is the minimum acceptable sales price at which you are willing to } \\
\text { sell } 100 \% \text { of your company's equity to a nonfamily member?" }\end{array}$ \\
\hline Emotional value & $\begin{array}{l}\text { Direct measurement: Emotional Value = WTA - PV (cash flows) - PV (private benefits of } \\
\text { control) } \\
\text { Indirect measurement: } \\
\text { Dependent variable: WTA or WTA divided by operating cash flow. } \\
\text { Control variables: all variables pertaining to the financial value of the firm (e.g., } \\
\text { leverage level, profitability, industry growth, industry beta) and variables explaining } \\
\text { financial private benefits of control (e.g., salary of the owner, private expenses } \\
\text { running through company accounts). } \\
\text { Independent variables: emotional benefits, emotional costs, moderating variables as } \\
\text { outlined in the research framework, demographic variables, community culture. }\end{array}$ \\
\hline $\begin{array}{l}\text { Perceived emotional } \\
\text { benefit from ownership }\end{array}$ & $\begin{array}{l}\text { Use Likert scales to determine the degree the owner actually values these benefits } \\
\text { (autonomy, power, challenge, continuity), or } \\
\text { Use attachment scales developed by Ball and Tasaki (1992) or Richins (1994a, 1994b). }\end{array}$ \\
\hline $\begin{array}{l}\text { Perceived emotional } \\
\text { cost from ownership }\end{array}$ & $\begin{array}{l}\text { Use Likert scales to determine the degree the owner actually experienced these costs } \\
\text { (occupational demand, exhaustion, role conflicts, responsibility, and isolation). } \\
\text { Use the Tetrick et al. (2000) scale to determine stress and strain of firm owners. } \\
\text { Directly measure sunk costs, as, for example, number of years spent building up the } \\
\text { firm, number of hours worked per week, gravity of work-family conflicts, using } \\
\text { Shepherd and Zacharakis's (2000) measures. }\end{array}$ \\
\hline $\begin{array}{l}\text { Emotional affection } \\
\text { with acquisition }\end{array}$ & $\begin{array}{l}\text { Investigate the degree to which the acquisition of the possession implied positive or } \\
\text { negative emotional affection (i.e., whether the acquisition was perceived as a } \\
\text { positive gift). }\end{array}$ \\
\hline Duration of ownership & Number of years or months. \\
\hline Affective commitment & Adapt the Meyer et al. (1993) measure for affective commitment to firm ownership. \\
\hline Marketability & $\begin{array}{l}\text { Determine the existence of an internal or external capital market or investigate the } \\
\text { number of shareholders as a proxy for potential buyers of ownership stakes. }\end{array}$ \\
\hline Exit costs & $\begin{array}{l}\text { Measure the level of firm-specific investment in human, social, and financial capital. } \\
\text { Use Meyer at al.'s measure for continuance commitment that develops as a result of } \\
\text { perceived exit costs. }\end{array}$ \\
\hline Community culture & Measure following Hofstede's (2001) works on community culture. \\
\hline
\end{tabular}

\section{References}

Aghion, P., \& Bolton, P. (1992). An incomplete contracts approach to financial contracting. Review of Economic Studies, 59(3), 473-494.

Anderson, R. C., \& Reeb, D. M. (2003). Founding-family ownership and firm performance: Evidence from the S\&P 500. Journal of Finance, 58(3), 1301-1327.

Ariely, D., Huber, J., \& Wertenbroch, K. (2005). When do losses loom larger than gains? Journal of Marketing Research, XLII, 134-138.

Arkes, H. R., \& Ayton, P. (1999). The sunk cost and Concorde effects: Are humans less rational than lower animals? Psychological Bulletin, 125(5), 591600 .
Ball, A. D., \& Tasaki, L. H. (1992). The role and measurement of attachment in consumer behavior. Journal of Consumer Psychology, 1(2), 155-172.

Baumol, W. J. (1990). Entrepreneurship: Productive, unproductive, and destructive. Journal of Political Economy, 98(5), 893-921.

Becker, G. S. (1974). A theory of social interactions. Journal of Political Economy, 82(6), 1063-1093.

Belk, R. W. (1987). Possessions and the extended self. Working paper. Salt Lake City, UT: University of Utah. Belk, R. W. (1988). Possessions and the extended self. Journal of Consumer Research, 15, 139-168.

Belk, R. W. (1991). The ineluctable mysteries of possessions. Journal of Social Behavior and Personality, 6(6), 17-55. 
Belk, R. W. (1992). Attachment to possessions. In S. M. Low \& I. Altman (Eds.), Place attachment: Human behavior and environment (pp. 37-62). New York: Plenum Press.

Bird, B., \& Brush, C. (2002). A gendered perspective on organizational creation. Entrepreneurship Theory \& Practice, Spring, 41-65.

Boyd, D. P., \& Gumpert, D. E. (1983). Growing concerns: Coping with entrepreneurial stress. Harvard Business Review, March-April, 44-64.

Carmon, Z., \& Ariely, D. (2000). Focusing of the forgone: How value can be so different to buyers and sellers. Journal of Consumer Research, 27, 360-370.

Chatterjee, S., Lubatkin, M. H., \& Schulze, W. S. (1999). Toward a strategic theory of risk premium: Moving beyond CAPM. Academy of Management Review, 24(3), 556-567.

Chrisman, J. J., Chua, J. H., \& Steier, L. (2005). Sources and consequences of distinctive familiness: An introduction. Entrepreneurship Theory and Practice, 29(3), 237-247.

Corbetta, G., \& Salvato, C. (2004). Self-serving or selfactualizing? Models of man and agency costs in different types of family firms: A commentary on "Comparing the agency costs of family and nonfamily firms: Conceptual issues and exploratory evidence". Entrepreneurship Theory and Practice, 28(4), 355.

Coursey, D. L., Hovis, J. L., \& Schulze, W. D. (1987). The disparity between willingness to accept and willingness to pay measures of value. Quarterly Journal of Economics, August, 679-690.

Csikszentmihalyi, M., \& Rochberg-Halton, E. (1981). The meaning of things: Domestic symbols and the self. Cambridge, MA: Cambridge University Press.

Demsetz, H., \& Lehn, K. (1985). The structure of corporate ownership: Causes and consequences. Journal of Political Economy, 93(6), 1155-1177.

Dittmar, H. (1989). Gender identity related meanings of personal possessions. British Journal of Social Psychology, 28, 159-171.

Douglas, E. J., \& Shepherd, D. A. (2000). Entrepreneurship as a utility maximizing response. Journal of Business Venturing, 15, 231-251.

Duhaime, I. M., \& Grant, J. H. (1984). Factors influencing decision-making: Evidence from a field study. Strategic Management Journal, 5, 301-318.

Dyck, A., \& Zingales, L. (2004). Private benefits of control: An international comparison. Journal of Finance, 59(2), 537-600.

Dyer, G., \& Whetten, D. A. (2006). Family firms and social responsibility: Preliminary evidence from the SP 500. Entrepreneurship Theory and Practice, September, 785-802.
Ehrhardt, O., \& Nowak, E. (2003). The effect of IPOs on German family-owned firms: Governance changes, ownership structure, and performance. Journal of Small Business Management, 41(2), 222-232.

Fama, E. F., \& Jensen, M. C. (1983). Agency problems and residual claims. Journal of Law and Economics, 26(2), 327-349.

Gimeno, J., Folta, T., Cooper, A., \& Woo, C. (1997). Survival of the fittest? Entrepreneurial human capital and the persistence of underperforming firms. Administrative Science Quarterly, 42(4), 750-783.

Gomez-Mejia, L. R., Larraza-Kintana, M., \& Makri, M. (2003). The determinants of executive compensation in family-controlled public corporations. Academy of Management Journal, 46(2), 226-237.

Gomez-Mejia, L. R., Nunez-Nickel, M., \& Gutierrez, I. (2001). The role of family ties in agency contracts. Academy of Management Journal, 44(1), 81-95.

Gomez-Mejia, L. R., Takacs Haynes, K., Nunez Nickel, M., Jacobson, K. J. L., \& Moyano-Fuentes, L. (2007). Socioemotional wealth and business risks in familycontrolled firms: Evidence from Spanish olive oil mills. Administrative Science Quarterly, 52, 106137.

Grossman, S. J., \& Hart, O. D. (1980). Takeover bids, the free-rider problem, and the theory of the corporation. Bell Journal of Economics, 11(1), 42-64.

Gulerce, A. (1991). Transitional objects: Reconsideration of the phenomenon. Journal of Social Behavior and Personality, 6(6), 187-208.

Handler, W. C. (1990). Succession in family firms: A mutual role adjustment between entrepreneur and next-generation family members. Entrepreneurship: Theory and Practice, 15(1), 37-51

Haneman, W. M. (1991). Willingness to pay and willingness to accept: How much can they differ? American Economic Review, 81(3), 635-647.

Harris, M., \& Raviv, M. (1988). Corporate control contest and capital structure. Journal of Financial Economics, 20, 55-86.

Herscovitch, L., \& Meyer, J. P. (2002). Commitment to organizational change: Extension of a threecomponent model. Journal of Applied Psychology, 87(3), 474-487.

Hirshleifer, D. (2001). Investor psychology and asset pricing. Journal of Finance, LVI(4), 1533-1597.

Hofstede, G. (2001). Culture's consequences, 2nd ed. Thousand Oaks, CA: Sage.

Horowitz, J. K., \& McConnell, K. E. (2002). A review of WTA/WTP studies. Journal of Environmental Economics and Management, 44, 426-447.

Kahneman, D., Knetsch, J. L., \& Thaler, R. H. (1990). Experimental tests of the endowment effect and 


\section{Zellweger, Astrachan}

the Coase theorem. Journal of Political Economy, 98, $1325-1348$

Kamptner, N. L. (1989). Personal possessions and their meanings in old age. In S. Spacapan \& S. Oskamp (Eds.), The social psychology of aging (pp. 165-196). Newbury Park, CA: Sage.

Kamptner, N. L. (1991). Personal possessions and their meanings: A life-span perspective. Journal of Social Behavior and Personality, 6(6), 209-228.

Kets de Vries, M. F. R. (1993). The dynamics of family controlled firms: The good and the bad news. Organizational Dynamics, 21(3), 59-71.

Knetsch,J.L.,\&Sinden,J.A. (1984).Willingness to pay and compensation demanded: Experimental evidence of an unexpected disparity in measures of value. Quarterly Journal of Economics, August, 507-521.

Knez, P., Smith, V. L., \& Williams, A. W. (1985). Individual rationality, market rationality, and value estimation. American Economic Review, 75(2), 397-402.

La Porta, R., Lopez-De-Silanes, F., Shleifer, A. \& Vishny, R. (2002) Investor protection and corporate valuation. Journal of Finance, 57(3), 1147-1170.

Le Breton-Miller, I., Miller, D., \& Steier, L. P. (2004). Toward an integrative model of effective FOB succession. Entrepreneurship Theory and Practice, 28(4), 305-329.

Mack, D. A., \& McGee, J. E. (2001). Occupational stress and the small business owner: The role of task complexity and social support. USASBE Conference paper proceedings.

Mayes, B. T., \& Ganster, D. C. (1988). Exit and voice: A test of hypotheses based on fight/flight responses to job stress. Journal of Organizational Behavior, 9, 199-216.

Meyer, J. P, Allen, N. J., \& Smith, C. A. (1993). Commitment to organizations and occupations: Extension and test of a three-component conceptualization. Journal of Applied Psychology, 78(4), 538-551.

Naughton, T. J. (1987). Quality of working life and the self-employed manager. American Journal of Small Business, 11, 33-40.

Price, L. L., Arnould, E. J., \& Folkman-Curasi, C. (2000). Older consumers' disposition of special possessions. Journal of Consumer Research, 7, 272-382.

Richins, M. L. (1994a). Special possessions and the expression of material values. Journal of Consumer Research, 21, 522-533.

Richins, M. L. (1994b). Valuing things: The public and private meanings of possessions. Journal of Consumer Research, 21, 504-521.

Schneider, B. (1987). People make the place. Personnel Psychology, 40(3), 437-453.

Schroeder, D. (2001). Membership and mission concerns of the board. Corporate Governance, 1(1), 15-26.
Schultz-Kleine, S., Kleine, R.E., \& Allen, C.T. (1995). How is a possession "me" or "not me"? Characterizing types and an antecedent of material possession attachment. Journal of Consumer Research, 22, 327-343.

Schultz-Kleine, S., \& Menzel-Baker, S. (2004). An integrative review of material possession attachment. Academy of Marketing Science Review, 1, 1-35.

Schulze, W. S., Lubatkin, M. H., Dino, R. N., \& Buchholtz, A. K. (2001). Agency relationships in family firms: Theory and evidence. Organizational Science, 12(2), 99-116.

Schumpeter, J. (1934). Capitalism, socialism. and democracy. New York: Harper \& Row.

Sharma, S., Chrisman, J. J., \& Chua, J. H. (1997). Strategic management of the family business: Past research and future challenges. Family Business Review, 10(1), $1-35$

Sharma, P., \& Manikutty, S. (2005). Strategic divestments in family firms: Role of family structure and community culture. Entrepreneurship Theory and Practice, 29(3), 293-312.

Shepherd, D. A. (forthcoming). Grief recovery from the loss of a family business: A multi- and meso-level theory. Journal of Business Venturing.

Shepherd, D. A., Wiklund, J., \& Haynie, J. M. (forthcoming). Moving forward: Balancing the financial and emotional cost of business failure. Journal of Business Venturing.

Shepherd, D. A., \& Zacharakis, A. (2000). Structuring family business succession: An analysis of the future leader's decision making. Entrepreneurship Theory and Practice, Summer, 25-39.

Shogren, J. F., Shin, S. Y., Haes, D. J., \& Kliebenstein, J. B. (1994). Resolving differences in willingness to pay and willingness to accept. American Economic Review, March, 255-268.

Sorenson, R. L. (1999). Conflict strategies used by successful family businesses. Family Business Review, 12(4), 325-339.

Strahilevitz, M. A., \& Loewenstein, G. (1998). The effect of ownership history on the valuation of objects. Journal of Consumer Research, 25, 276-289.

Tagiuri, R., \& Davis, J.A. (1992). On the goals of successful family companies. Family Business Review, 5(1),43-62. Tetrick, L. E., Slack, K. J., Sinclair, R. R., \& Da Silva, N. (2000). A comparison of the stress-strain process for business owners and nonowners: Differences in job demands, emotional exhaustion, satisfaction, and social support. Journal of Occupational Health Psychology, 5(4), 464-476.

Thaler, R. (1980). Toward a positive theory of consumer choice. Journal of Economic Behavior and Organization, 1(1), 39-60. 
Thaler, R. (1983). Illusions and mirages in public policy. Public Interest, 73, 60-74.

Tuan, Y. F. (1980). The significance of the artifact. Geographical Review, 70(4), 462-472.

Villalonga, B., \& Amit, R. (2006). How do family ownership, control and management affect firm value? Journal of Financial Economics, 80(2), 385-417.

Wallendorf, M., \& Arnould, E. J. (1988). "My favourite things": A cross cultural inquiry into object attachment, possessiveness, and social linkage. Journal of Consumer Research, 14, 531-547.

Wapner, S., Demick, J., \& Redondo, J. P. (1990). Cherished possessions and adaptation of older people to nursing homes. International Journal of Aging and Human Development, 31, 219-235.

Ward, J. (1997). Growing the family business: Special challenges and best practices. Family Business Review, 10(4), 323-337.

Watson, L. (1992). The secret life of inanimate objects. Rochester, VT: Destiny Books.

Watson, L., Lysosnki, S., Gillan, T., \& Raymore, L. (2002). Cultural values and important possessions: A crosscultural analysis. Journal of Business Research, 55, 923-931.

Weil, S. (1952). The need for roots: Prelude to a declaration of duties towards mankind. London: Routledge \& Kegan Paul. (Original work published 1949)
Westhead, P., \& Cowling, M. (1997). Performance contrasts between family and non-family unquoted companies in the UK. International Journal of Entrepreneurial Behaviour and Research, 3, 30-52.

Winnicott, D. W. (1953). Transitional objects and transitional phenomena. International Journal of Psychoanalysis, 34, 89-97.

Zahra, S. (1993). A conceptual model of entrepreneurship as firm behavior: A critique and extension. Entrepreneurship Theory and Practice, 17(4), 5-21.

Zellweger, T. (2006). Risk, return and value in the family firm. Dissertation at the University of St. Gallen.

Thomas M. Zellweger, University of St. Gallen and Babson College, Dufourstrasse 40a, 9000 St. Gallen; tel: 4171224 7100; thomas.zellweger@unisg.ch. Joseph H. Astrachan, Cox Family Enterprise Center, Wachovia Chair in Family Business, Management and Entrepreneurship Department, Coles College of Business, Kennesaw State University; Joe_Astrachan@coles2.Kennesaw.edu. 